\title{
Understanding intention to quit amongst artisans and engineers: The facilitating role of commitment
}

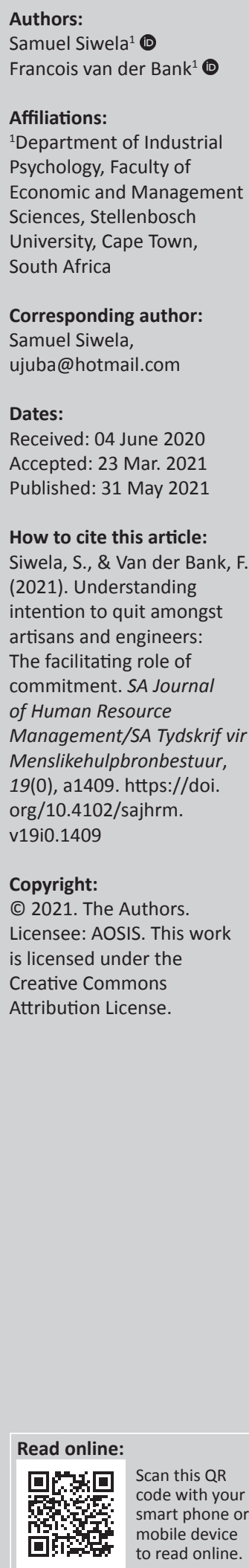

Orientation: Given the critical shortage of skilled artisans and engineers in the job market, retention of this key talent is of paramount importance.

Research purpose: The aim of this study was to identify the determinants of affective commitment and investigate the impact thereof on intention to quit (ITQ) amongst artisans and engineers.

Motivation for the study: For human resource management interventions to be effective in retaining artisans and engineers, the constructs underlying commitment and stay intentions need to be understood. Whereas previous studies have mostly focussed on bivariate relationships, the current study was motivated by the need to develop and test an integrative explanatory model.

Research approach/design and method: A non-probability convenience sample of 154 artisans and 84 engineers employed in a manufacturing engineering company participated in this study. A cross-sectional design was employed, with structural equation modelling as analysis technique.

Main findings: The data supported the central role of affective commitment in reducing ITQ amongst artisans and engineers. Job fit, psychological meaningfulness, perceived organisational support and satisfaction with pay all explained significant variance in affective commitment, whilst affective commitment demonstrated a strong negative relationship with ITQ. It was found that although perceived organisational justice does not necessarily create affective commitment, people are more likely to quit when they experience injustice.

Practical/managerial implications: For organisations to retain artisans and engineers, they have to foster both affective commitment and organisational justice. Affective commitment can be facilitated by interventions focusing on job fit, meaningful work, organisational support and satisfaction with pay.

Contribution/value-add: This study provides practical insights into the antecedents of ITQ amongst artisans and engineers, informing human resource management interventions aimed at better retention.

Keywords: affective commitment; intention to quit; artisan; engineer; retention; job satisfaction.

\section{Introduction}

\section{Background}

South Africa is facing a critical shortage of professional engineers and artisans, hampering the country's efforts towards achieving the National Development Plan (NPL) (Joint Initiative on Priority Skills Acquisition, 2010; Mzabalazo advisory services, 2014; Nyatsumba, 2017; Xpatweb, 2020). This has serious economic implications for the country, including constraints to infrastructure development (Breier, 2009), low productivity and competitiveness in industries such a mining, construction and manufacturing (MerSETA, 2018; Reddy, Rogan, Mncwango, \& Chabana, 2017; The Department of Trade and Industry, 2015; Tshele \& Agumba, 2014); and fewer skilled workers available to accelerate small business development (Local Government Sector Educational and Training Authority, 2016).

Several government-sponsored initiatives have investigated the reasons for the scarcity of these critical skills in South Africa (Du Toit \& Roodt, 2009; Joint Initiative on Priority Skills Acquisition, 2010; Mukora, 2009). 
Reasons for the low supply of artisanal and engineering skills have been linked to ineffective career guidance, privatisation of some state-owned enterprises (SOEs), organisations cutting down on training development budgets, movement from the traditional apprenticeship system to learnerships, lack of opportunities for experiential learning, the quality and relevance of training provided by technical vocational education and training (TVET) colleges (Pretorius, 2018) and unattractive salaries and wages (Mzabalazo Advisory Services, 2014). For professional engineers, reasons also include the shortage of matriculants who meet the criteria to gain entrance to formal university programmes, transformation policies and the status of engineering professionals in relation to other lucrative careers such as chartered accountants (Du Toit \& Roodt, 2009). To make matters worse, high demand internationally for skilled workers have over the years led to widespread recruitment of experienced artisans and engineers by international recruitment agencies (Breier, 2009).

As the shortage of artisanal skills is evidently not a simple problem; it is a systemic problem that have plagued South Africa for decades. Various initiatives have been attempted to address the skills shortage problem in South Africa (Breier, 2009). More recently, the government has developed the National Artisan Development Strategy and Implementation plan (Department of Higher Education and Training, 2018). However, despite various enquiries, reforms and investment in training and development, creating sufficient capacity in artisanal and engineering skills remains a challenge (Department of Higher Education and Training, 2020; Xpatweb, 2020). Whilst the decline of apprenticeship numbers and the increasing need for artisanal and engineering skills are a global phenomenon (Gow, Warren, Anthony, \& Hinschen, 2008; Mukora, 2009), the consequences are more severe for developing countries, such as South Africa, that strongly rely on these trades for economic growth and job creation (Breier, 2009; SA Commercial Prop News, 2013).

Skills scarcity does not only affect the broader economy; it also directly affects the productivity and competitiveness of those organisations that rely on these scarce skills - especially at a time when large proportions of experienced individuals are going into retirement (Breier, 2009). Whilst organisations can do much more to increase the supply of artisans and engineers through apprenticeships and other initiatives, retaining talent in this area is reportedly a challenge (Schlechter, Faught, \& Bussin, 2014). Voluntary turnover is said to plague many organisations because of the undersupply and over-demand of some of these technical skills (Tshele \& Agumba, 2014; Xpatweb, 2020), making it easier for employees to 'shop around' for more satisfying job opportunities. This of course puts organisations under pressure to hold onto these skills, especially when it may not be feasible for them to compete in terms of salaries.

As alluded to earlier, the skills scarcity is further exacerbated by the talent war brought about by globalisation (Beechler \&
Woodward, 2009; Michaels, Handfield-Jones, \& Axelrod, 2001). Various indicators suggest that South Africa is losing these skills to other countries for reasons such as higher salaries, development opportunities and prospects of better living standards (Breier, 2009; Xpatweb, 2020). Thus, given the scarcity of the skills, organisations need to be intentional about developing strategies to retain the people they already have. To achieve this objective more insight is required into the psychological processes underpinning the continued attachment and stay intentions of artisans and engineers.

\section{Contribution}

Whilst extensive research has been carried out on psychological states, job attitudes and experiences related to turnover intentions such as overall job satisfaction, organisational commitment, work group cohesion and support, autonomy, organisational justice, promotional chances and alternative job opportunities (see the meta-analysis by Griffeth, Hom, \& Gaertner, 2000), relatively few studies have applied these explanatory models to the context of engineers and artisans. (Note that this does not include software or information and communications technology workers, also sometimes referred to as engineers). Interestingly, four of the only seven artisanal and engineering-related studies identified by the authors were conducted in South Africa, of which all are published in the South African Journal of Human Resource Management confirming the prevalence and need to curb turnover intentions locally. The other two studies were carried out on construction engineers in Taiwan (Sun, 2011) and Australian male apprentices (Gow et al., 2008).

According to Sun (2011), pay and promotion satisfaction and affective commitment are two major factors influencing turnover intentions amongst engineers in Taiwan, whilst Gow et al. (2008) found that an intrinsic motivation orientation, job satisfaction, working conditions and geographic location are significant predictors of staying in an apprenticeship in Australia. In South Africa, a descriptive study by Jordaan and Barry (2009) found that based on a 79-person survey consisting of various job factors, remuneration is one of the predominant reasons for artisan dissatisfaction. A study by Schlechter et al. (2014) on artisan attraction and retention shed further light on the impact of remuneration, but from a total reward perspective. Interestingly, work-life balance (a non-financial reward) was considered most important by participants, followed by compensation level and variable pay. Also motivated by the need to improve retention strategies in the engineering environment in South Africa, Coetzee, MitongaMonga, \& Swart (2014) examined the impact of various human resource practices on organisational commitment. Using the three forms of organisational commitment (i.e. affective, continuance and normative) as dependent variables, the authors regressed 13 organisational human resource (HR) practices separately on each of the three forms of commitment and found that training and development and rewards and remuneration were important predictors of both affective and normative commitment, whilst affective commitment was also 
influenced by job satisfaction. A modest proportion of $4 \%$ of variances was explained in continuance commitment with human resource policies and procedures identified as the only significant predictor. These findings corroborate the results of an earlier qualitative study by Van Rooyen, Du Toit, Botha and Rothmann (2010) conducted amongst 14 artisans, also in a South African organisation. According to their findings, remuneration and development opportunities were the two highest ranking factors for the retention of artisans. Other important factors included equality, management and the work environment and work relationships.

Building on the relatively few available studies, this study also set out to investigate turnover intentions within the context of engineers and artisans - two occupations identified as critical for economic growth and development in South Africa. Whilst it needs to be acknowledged that professional engineers and artisans are not completely homogeneous groups, there are a number of similarities between the two groups - making it useful to study them together. Both are highly technically orientated and often artisans are a steppingstone for becoming an engineer. The two groups also work closely together on projects and both are considered as critical skills resources. These similarities were especially evident in the company in which the study was conducted as the engineers were mostly of the electrical and mechanical type, working with physical objects such as generators and diesel engines. Moreover, for the same reasons explained above, research and newspaper reports sometimes refer to these groups as a collective (The Department of Trade and Industry, 2015), and a professional society such as Artisan, Technician and Engineers Association Africa (ATEAA) represents the combined interests of these groups. Technical vocational education and training colleges also refer to technical orientated artisan programmes as engineering programmes (Mukora, 2008).

What makes this study unique is that it incorporates a relatively wide range of factors, with the focus on explicating the inter-relationships between the variables using structural equation modelling. This approach is different from that of, for example, Coetzee et al. (2014) who investigated the impact of various job factors on organisational commitment, but without considering the subsequent effect of commitment on turnover intentions. Neither did their study consider the pathways between the independent variables. The aim of this study was therefore to shed light on the complex nomological net or psychological processes explaining turnover intentions amongst engineers and artisans. Whilst many years later, this approach is an attempt to respond to a call from Mobley, Griffeth, Hand and Meglino (1979) for process-based, multivariate studies:

Such studies are necessary in order to interpret the relative efficacy of numerous variables and constructs thought to be related to turnover, to resolve apparently contradictory bivariate studies, to attempt to account for a greater proportion of the variance in turnover and to move toward a more complete understanding of the turnover process. (p. 510)
Against the backdrop of developing a turnover intention structural model, the authors of this study identified affective commitment as a central feature in the psychological process. There is compelling research evidence that shows that affective commitment is one of the strongest predictors of turnover intentions and also a key mediator variable (Chênevert, Vandenberghe, \& Tremblay, 2015; Fazio, Gong, Sims, \& Yurova, 2017; Meyer, Stanley, Herscovitch, \& Topolnytsky, 2002; Saleem \& Qamar, 2017; Wong \& Wong, 2017). Moreover, unlike continuance commitment, affective commitment is also linked to high attendance, extra-role effort and resiliency in pursuit of organisational goals (Chênevert et al., 2015; Meyer et al., 2002). This implies that organisations can benefit from an in-depth understanding of the antecedents of affective commitment because high affective commitment results in engaged employees and low withdrawal behaviours such as absenteeism and quit decisions.

\section{Research purpose and objectives}

In summary, the purpose of this study was to come to a better understanding of the centrality of affective commitment for the retention of artisanal and engineering skills. To this effect, an integrated structural model was developed about the antecedents of organisational commitment amongst artisans and engineers and the effect thereof on their intention to quit (ITQ). More specifically, based on a review of previous studies on voluntary turnover, this study investigated the following antecedents: (1) affective commitment, (2) perceived organisational justice, (3) satisfaction with pay, including pay level, benefits, pay structure and administration, (4) perceived organisational support, (5) job fit, (6) satisfaction with career advancement and development opportunities and (7) work meaningfulness.

\section{Literature review Intention to quit}

The study of employee turnover is complicated by the fact that people are not available for research once they have left the organisation. To address this conundrum, many studies on voluntary turnover (mostly cross-sectional studies) have used ITQ as a proxy variable for voluntary employee turnover (Bothma \& Roodt, 2013; Griffeth et al., 2000; Wong \& Wong, 2017). Although ITQ does not necessarily result in the decision to quit, various conceptual and empirical evidence suggests that voluntary turnover is the next logical step when people express the intention to leave an organisation (Firth, Mellor, Moore, \& Loquet, 2004; Fishbein \& Ajzen, 1975; Mobley et al., 1979). Investigating the determinants of ITQ is therefore a practical alternative for studying turnover behaviour.

\section{Affective commitment and intention to quit}

Affective commitment is one of the single most important variables in studies involving employee turnover. 
A review of turnover literature by Mobley et al. (1979) found that commitment-attachment exceeds overall job satisfaction as the strongest predictor of turnover behaviour. Likewise, a meta-analysis by Griffeth et al. (2000) showed the importance of the contribution of organisational commitment as a proximal precursor in the withdrawal process.

In Meyer and Allen (1991) three-component model of organisational commitment, affective commitment is distinctively different from normative and continuance commitment. Whilst normative commitment arises from reciprocity and continuance commitment from the perceived losses associated with leaving the organisation, affective commitment represents a state of emotional attachment to the organisation based on value congruence. Simply put, with affective commitment, people stay with an organisation because they want to and not because they feel obliged or pressurised to do so. Given the conceptualisation of affective commitment, it is not surprising that compared with the other two forms of commitment, affective commitment has the strongest relationship with ITQ (Meyer et al., 2002). Moreover, as mentioned earlier, affective commitment is also connected with various pro-social and organisational citizenship behaviours (Chênevert et al., 2015), whilst this is not necessarily true for the other two forms of commitment. In fact, it could be argued that continuance commitment could potentially decrease performance if employees stay for the wrong reasons, such as not to lose out on their pension benefits (Dulebohn, Molloy, Pichler, \& Murray, 2009).

It is therefore plausible to propose that organisations that are able to influence the affective commitment of their workforce would be in a better position to retain them because of the employees' emotional attachment to, identification with and involvement with the organisation (Meyer \& Allen, 1991). It is subsequently proposed that affective commitment would be negatively related to ITQ amongst artisans and engineers:

H1: Affective commitment is negatively related to ITQ.

The previous section explained that affective commitment represents the emotional ties that employees have with their organisations, making it a key variable in predicting turnover intentions. To this effect, various studies have shown that organisational commitment is an important mediator between various job and organisational characteristics and voluntary turnover (Chênevert et al., 2015; Fazio et al., 2017; Saleem \& Qamar, 2017; Wong \& Wong, 2017). The question therefore is, 'what are the factors influencing the affective commitment of artisans and engineers?' According to Meyer and Allen (1991), affective commitment develops from work experiences that satisfy employees' needs and/or that are compatible with their values. Such experiences are necessary for them to feel comfortable psychologically and to experience feelings of competence. Using this as a guiding theory for understanding the mechanisms underlying affective commitment, along with previous research on turnover intentions amongst artisans and engineers, the following antecedents were considered: perceived organisational justice, satisfaction with pay, job fit, satisfaction with career advancement and development opportunities and work meaningfulness.

\section{Perceived organisational justice and affective commitment}

Experiences of injustice signal that employees' needs and values are not being met (Ilies, Lanaj, Pluut, \& Goh, 2018).

When employees perceive to be treated unfairly, they often experience emotions of fear, anger, hopelessness, sadness decreased emotionality, coupled with a sense of being out of control (Park et al., 2016; Taris et al., 2004). It has been shown that these affective reactions create feelings of psychological discomfort or even emotional exhaustion, resulting in employees distancing themselves emotionally from the organisation (i.e. low affective commitment) as a form of psychological withdrawal, which precedes behavioural responses (i.e. turnover) (Cole et al., 2010; Latham \& Pinder, 2005). Taris, Horn, Van Schaufeli and Schreurs (2004) explained that psychological withdrawal (lack of commitment) can be considered a strategy to cope with the emotional stress and frustration resulting from perceived unfairness. This is in line with Meyer and Allen's (1991) explanation that for employees to develop affective commitment, they need to feel comfortable psychologically. From an employeeorganisational relationship (OER) perspective it can also be argued that employees suppress parts of themselves because they feel that given current, or expected future injustice, investment in the relationship is not worth it (Lee et al., 2017).

Perceived organisational justice is epitomised by three core dimensions, that is, distributive, procedural and interactional justice (Colquitt, Conlon, Wesson, Porter, \& Ng, 2001). Distributive justice refers to the fairness that is perceived when one evaluates how outcomes such as benefits and rewards are distributed and how resources are allocated.

Procedural justice refers to perceptions of fairness that emanate from issues concerning methods, mechanisms, processes and procedures used to determine outcomes, whilst interactional justice refers to the fairness perceptions with regard to how individuals are treated and the truthfulness of information they receive when organisational processes and procedures are implemented. Meta-analytic studies have shown that organisational justice, in particular procedural and distributive justice, is positively and significantly related to organisational commitment (CohenCharash \& Spector, 2001; Colquitt et al., 2001). Moreover, while some have considered perceived organisation justice to be a culturally sensitive variable, a study among airline workers in Jordan suggests that justice perceptions are a significant predictor of organisational attitudes also in developing countries (Suifan et al., 2017). It is thus postulated that perceived organisational justice will be positively related to affective commitment: 
H2: Perceived organisational justice is positively related to affective commitment.

\section{Satisfaction with pay and affective commitment}

Satisfaction with pay refers to the extent of the overall positive or negative affect that individuals have towards their pay (Micheli \& Lane, 1991, as cited in Williams, McDaniel, \& Nguyen, 2006), representing an important facet of overall job satisfaction, that contributes to need fulfilment (Williams et al., 2006). Satisfaction with pay is conceptualised as consisting of four dimensions, that is, satisfaction with pay level, benefits, pay rise, and pay structure and administration. Pay satisfaction is maximised when these match employees' personal preferences (Bussin \& Brigman, 2019). Previous research has shown that related remuneration and benefits as well as non-monetary incentives play an important role in enhancing an employee's affective commitment (Coetzee et al., 2014; Kuvaas, 2006; Lumley et al., 2011; Nujjoo \& Meyer, 2012; Schlechter et al., 2014). Of note here is the study by Kuvaas (2006) that showed that pay satisfaction influences affective commitment when controlling for justice perceptions. This suggests that the emotional experience of pay satisfaction itself, and not only perceived feelings of fairness (a by-product of pay comparisons), contributes to affective commitment, thus highlighting the need-fulfilling function of pay satisfaction. Although pay on its own is no absolute guarantee of affective commitment, it can be posited that artisans and engineers who have a higher degree of satisfaction with pay are more likely to develop an emotional attachment or bond with the organisation. It is therefore proposed that satisfaction with pay will be positively related to affective commitment:

H3: Satisfaction with pay is positively related to affective commitment.

\section{Perceived organisational justice and satisfaction with pay}

In addition to the hypothesised direct effect of perceived organisational justice on affective commitment, it is posited that perceived organisational justice can influence affective commitment indirectly via its influence on pay satisfaction. The relationship between justice perceptions and satisfaction with pay is well established in the literature (Arnold \& Spell, 2006; Dulebohn \& Werling, 2007; Fong \& Shaffer, 2003; Haynie et al., 2016; SimanTovNachlieli \& Bamberger, 2020). A meta-analysis by Colquitt et al. (2001) indicated that distributive justice had the strongest relationship with pay satisfaction, followed by procedural justice. The relationship between distributive justice and satisfaction with pay is rooted in equity theory (Adams, 1963). Equity theory states that employees tend to compare their perceived output-input ratio with referent others, where output refers to salaries and input refers to qualifications, performance and experience. If employees perceive their output-input ratio to be less than that of referent others, they experience inequity and feel underreward, which causes dissatisfaction with their pay. The assumptions of equity of theory are well supported by empirical research (Dulebohn \& Werling, 2007; Till \& Karren, 2011). This is especially relevant for artisans since the union-based environment in which they operate does not always allow for pay differentials based on performance. Van Rooyen et al. (2010) found that artisans were disgruntled that the merit system did not fairly reward exceptional performers because despite their performance, the pay increase is negotiated by unions.

Therefore, high performing artisans who contribute more to business success may feel a strong sense of injustice that their salaries are the same as everyone even though they perceive themselves to contribute the most to the success of the organisation:

H4: Perceived organisational justice is positively related to satisfaction with pay.

\section{Perceived organisational support and affective commitment}

Perceptions of being cared for and valued by one's organisation enhance self-esteem, sense of belonging and affiliation (Rhoades, Eisenberger, \& Armeli, 2001). As explained earlier, affective commitment is developed by work experiences that foster psychological contentment and feelings of competence (Meyer \& Allen, 1991). It can thus be argued that when artisans and engineers view their organisation as caring and valuing their contributions, they will be more likely to develop an emotional bond or attachment with their organisation.

Such an emotional bond or attachment influences the employees to reciprocate by behaving in ways that benefit the organisation, and therefore they will be willing to stay in the organisation.

Ample empirical evidence exists to corroborate a positive association between perceived organisational support and affective commitment (Chênevert et al., 2015; Kim et al., 2016b; O'Driscoll \& Randall, 1999; Saks, 2006; Wong \& Wong, 2017). A study by Kim et al. 2016b reported a positive and significant correlation $(r=0.67, p<0.01)$ between perceived organisational support and affective commitment.

Furthermore, other studies have indicated that perceived organisational support has a direct impact on affective commitment and an indirect impact on turnover intentions through affective commitment (Addae, Parboteeah, \& Davis, 2006; Wong \& Wong, 2017). Therefore, it is plausible to propose that perceived organisational support will be positively related to affective commitment.

H5: Perceived organisational support is positively related to affective commitment.

\section{Job fit and affective commitment}

Job fit is a dimension of job embeddedness that falls within the theoretical domain of person-job fit (P-J fit) (O'Reilly, 
Chatman, \& Caldwell, 1991). Job fit refers to the congruence and compatibility of an employee's skills, knowledge and abilities and the demands of the job or the alignment between the needs, desires and values of the employee and what the job provides (Edwards, 1991). When a strong match exists between what the employee desires and what the job offers, the employee will be more likely to experience his or her needs being met, which is necessary for producing affective commitment (Meyer \& Allen, 1991). In addition, when employees have the right skills for the job, they will experience feelings of competence, also an important determinant of affective commitment. Various studies have reported a positive relationship between job fit and affective commitment and employee retention (Holtom, Lee, \& Tidd, 2002; Hom et al., 2009; Kooij \& Boon, 2018; Kristof-Brown, Zimmerman, \& Johnson, 2005; Mitchell, Holtom, Lee, Sablynski, \& Erez, 2001; Tebele, Van Dyk, \& Coetzee, 2013). It can therefore be expected that when artisans and engineers are able to successfully apply their technical knowledge and skills, whilst working in an environment tailored to their unique needs, they will be more likely to develop feelings of affective commitment to the organisation.

It is therefore proposed that job fit will be positively related to affective commitment of artisans and engineers:

H6: Job fit is positively related to affective commitment.

\section{Satisfaction with career advancement opportunities and affective commitment}

At least three of the studies on artisan and engineer turnover intentions highlighted the impact of training and development opportunities and promotion satisfaction (Coetzee et al., 2014; Sun, 2011; Van Rooyen et al., 2010). In the qualitative study by Van Rooyen et al. (2010), some participants expressed their dissatisfaction with limited promotional opportunities because of what they referred to as 'rigid implementation of employment equity requirements'.

In the 21st century, career development and advancement no longer denotes advancing up the career ladder but also means being affording the employee diverse opportunities such as stretch assignments, lateral moves and multiple project works that help build and broaden the employee's skills and competency levels (Arthur, 2014; Baruch, 2004). Employees who are satisfied with their career advancement opportunities are therefore more likely to develop a strong emotional attachment or bond with their organisation (Fletcher, 2016; Hirschi, 2018; Meyer \& Allen, 1991). Researchers have indicated that organisations that provide career development and mobility opportunities are more likely to positively influence the affective commitment of their employees (Putri \& Setianan, 2019; Robbins, 1993; Weng, McElroy, Morrow, \& Liu, 2010). It is therefore proposed that satisfaction with career development and advancement opportunities will be positively related to affective commitment of artisans and engineers:

H7: Satisfaction with career advancement opportunities is positively related to affective commitment.

\section{Work meaningfulness and affective commitment}

Meaningfulness is a psychological state or experience that refers to 'the degree to which the employee experiences the job as one which is generally meaningful, valuable and worthwhile' (Hackman \& Oldham, 1976, p. 256). According to May, Gilson and Harter (2004, p. 14), the meaningfulness of work is 'judged in relation to an individual's own ideals or standards'. Work is more likely to be experienced as meaningful when it offers variety, requires responsibility for the whole task, has a significant impact in or outside the organisation (Hackman \& Oldham, 1976) and is considered challenging, but not overwhelming (Atkinson, 1964; Locke, Mento, \& Katcher, 1978).

The provision of exciting, meaningful and challenging work is a leading factor for engaging and retaining employees regardless of industry, economic conditions and business challenges (Bailey, Yeoman, Madden, Thompson, \& Kerridge, 2019; Fletcher, 2016; Kaye \& Jordan-Evans, 2002; Sutherland \& Jordaan, 2004). Research findings indicate that psychological meaningfulness has a significant positive influence on employees' work attitudes, including affective commitment (Chalofsky \& Krishna, 2009; Jiang \& Johnson, 2018; Song, Yu, Zhang, \& Jiang, 2015; Willemse \& Deacon, 2015). According to Jiang and Johnson (2018), employees tend to reflect positively on meaningful work which explains the emotional bond with their organisation. It can subsequently be argued that artisans and engineers who view their tasks and job content as challenging and purposeful are more likely to have a sense of emotional attachment with their organisation and, therefore, will be less likely to leave the organisation:

H8: Work meaningfulness is positively related to affective commitment.

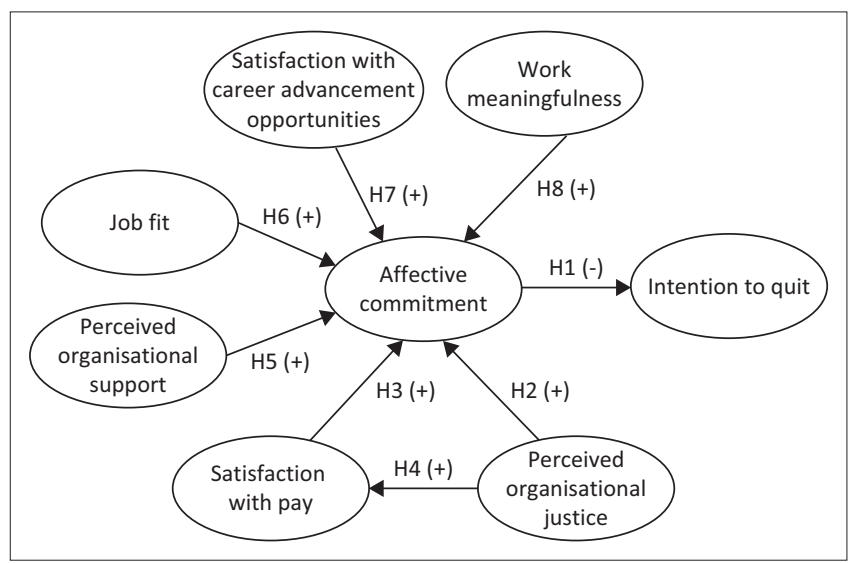

FIGURE 1: Proposed integrated model of intention to quit amongst artisans and engineers. 


\section{Proposed structural model}

The foregoing discussion highlighted the centrality of affective commitment as a core antecedent of ITQ, and proposed several variables influencing affective commitment amongst artisans and engineers.

Figure 1 outlines the relationships between the latent variables. The structural model represents the overarching research hypothesis concerning the psychological mechanism explaining variance in affective commitment and the concomitant influence thereof on ITQ.

\section{Research design Research approach}

This study utilised a cross-sectional correlational design with the information collected through a survey. Such a design lends itself well to evaluating the relationships between two or more variables where the researcher does not have control of the independent variables as their manifestations have taken place or cannot be influenced by the researcher (Kerlinger \& Lee, 1964; Landy \& Conte, 2013). Whilst correlational studies do not prove causality between the variables of interest (Kerlinger \& Lee, 1964), Spector (2019, p. 1) argued that a welldesigned cross-sectional study underpinned by theorising 'can provide evidence for relationships amongst variables and can be used to rule out many potential alternative explanations for those relationships'.

\section{Research method \\ Research participants}

Research participants in this study were drawn from a large manufacturing and engineering company that has operations across South Africa. A non-probability sampling method using convenience sampling was utilised to collect data from 238 employees. The participants consisted of 154 artisans $(64.7 \%)$ and 84 engineers $(35.3 \%)$ - the company employed a total of 317 artisans (response rate of $48.58 \%$ ) and 115 engineers (response rate of $73.04 \%$ ) at the time of the study. The sample was predominantly male-dominated (91.6\%). The majority of participants $(45.8 \%)$ were from the age group of 25-34 years, followed by 35-44 (31.1\%), 45-54 (10.5\%), 18$24(9.7 \%)$ and more than 55 years $(2.9 \%)$. The majority of participants were Africans (66.8\%) followed by white people $(18.5 \%)$, whilst mixed race and Indian participants constituted $9.2 \%$ and $5.5 \%$ of the sample, respectively.

\section{Measuring instruments}

A total of eight instruments were used to operationalise the latent variables in the structural model. Except for the ITQ Scale, all scales utilised a five-point rating scale ranging from 1 (strongly disagree) to 5 (strongly agree). The ITQ Scale used a six-point scale ranging from 1 (never) to 6 (always).

Affective commitment was measured using the affective commitment subscale of the Organisational Commitment Scale (OCS) (Meyer \& Allen, 1991). The affective commitment subscale measures the emotional bond or attachment that an employee has with the organisation. The subscale consists of six items, including, for example, the item 'I do not feel emotionally attached to my organisation'. Van Dyk, Coetzee and Tebel (2013) obtained a Cronbach's alpha of 0.90 for the affective commitment subscale. The current study yielded a Cronbach's alpha of 0.81 for the original scale and 0.86 after discarding two potentially problematic items. The unidimensionality of the reduced affective commitment subscale was confirmed using the eigenvalues-greater-thanunit rule and the four items loaded high $(>0.70)$ on the single underlying factor.

Satisfaction with pay was measured using the multidimensional pay satisfaction questionnaire (Heneman \& Schwab, 1985) that consists of four subscales, namely, pay level, benefits, pay raise, and pay structure and administration. The pay satisfaction questionnaire consists of 18 items that measure the respondents' level of satisfaction with pay level (4 items), benefits (4 items), pay raise (4 items) and pay structure and administration (6 items). Sample items for the respective subscales include: 'I am satisfied with my overall level of pay', 'I am satisfied with my benefit package', 'I am satisfied with the raises I have typically received in the past' and 'I am satisfied with how the company administers pay'. Panaccio, Vandenberghe and Ben-Ayed (2014) reported highly satisfactory Cronbach's alpha for pay level (0.96), pay raise (0.90), benefits (0.95) and pay structure and administration (0.95). This study also yielded satisfactory Cronbach's alphas for pay level (0.97), benefits (0.94), pay raise (0.85) and pay structure and administration (0.89). Each of the subscales of the pay satisfaction questionnaire was confirmed to be unidimensional and all factor loadings were significant, with values ranging from 0.64 to 0.97 .

Perceived organisational justice was measured in this study using distributive and procedural justice subscales (Colquitt et al., 2001). The distributive justice subscale measures the perceived level of fairness with regard to how outcomes such as benefits and rewards are distributed and allocated, whilst the procedural justice subscale measures the perceived level of fairness with how procedures, processes, mechanisms and methods are applied to determine outcomes. The distributive justice subscale consists of four items (e.g. 'Are the outcomes you receive appropriate for the work you have completed?') and the procedural justice subscale consisted of seven items (e.g. 'Have you been able to appeal the outcomes arrived at by those procedures?'). Colquitt and Rodell (2011) obtained acceptable Cronbach's alpha score for procedural justice subscale ( 0.86 for time 1 and 0.90 for time 2 ) and distributive justice subscale ( 0.97 for time 1 and 0.90 for time 2 ) in their longitudinal study. The Cronbach's alpha values in this study were 0.87 for the distributive justice subscale and 0.90 for procedural justice subscale. The unidimensionality of each subscale was confirmed and with the factor loadings above 0.70 .

Job fit was measured using the nine-item job fit subscale of the Job Embeddedness Scale (JES) (Mitchell et al., 2001). The 
job fit subscale measures the degree to which there is compatibility and congruence between the demands of the job and skills, abilities and competencies required in the job and those possessed by the employee. Representative sample items include 'I fit with the company's culture' and 'My job utilises my skills and talents well'. The job fit subscale has demonstrated reliable internal consistency, with a Cronbach's alpha of 0.84 (Ferreira, Coetzee, \& Masenge, 2013) and 0.81 (Takawira, Coetzee, \& Schreuder, 2014). The current study yielded an acceptable Cronbach's alpha of 0.85, thereby indicating high internal consistency. During item analysis and dimensionality analysis, two items were flagged as problematic items and were subsequently deleted. The remaining seven items had factor loadings between 0.60 and 0.76 and loaded on a single factor, thereby collaborating the unidimensionality of the job fit subscale.

Perceived organisational support was measured using an eightitem shortened version of the Perceived Organisational Support Scale (Rhoades et al., 2001). This scale measures the extent to which an employee perceives that the organisation cares about him or her and values his or her contribution. Sample items for the scale include, 'My organisation really cares about my well-being' and 'My organisation is willing to help me if I need a special favour'. Rhoades et al. (2001) and Saks (2006) obtained Cronbach's alpha coefficients for the shorter version of the Perceived Organisational Support Scale that are above 0.70 . The current study yielded a Cronbach's alpha of 0.89 , which demonstrates high internal consistency. Item analyses flagged two reverse-scored items to be problematic and were subsequently deleted. The remaining six items had factor loadings between 0.63 and 0.85 on a single underlying factor, thereby collaborating the unidimensionality of the scale.

Meaningfulness was measured using the Psychological Meaningful Scale (PMS) (May et al., 2004). This scale comprises six items and assesses the extent to which an employee derives meaning from work-related activities (e.g. 'My job activities are personally meaningful to me'). The PMS has demonstrated reliable internal consistency, with Cronbach's alpha of 0.90 (May et al., 2004). The current study yielded a Cronbach's alpha of 0.93 , which demonstrates high levels of internal consistency. All items loaded on a single factor with loadings above 0.70 , thereby confirming the unidimensionality of the PMS.

Satisfaction with career advancement opportunities was measured using a 15-item multidimensional organisational growth scale (Weng \& Hu, 2009). The organisational career growth scale comprises four dimensions, namely, career goals progress (four items), professional ability development (four items), promotion speed (four items) and remuneration growth (three items). The last dimension, growth of remuneration (three items), was excluded because of its overlap with the satisfaction with pay questionnaire. Kim et al. (2016a) obtained reliable Cronbach's alpha coefficients of $0.94,0.94$ and 0.89 for career goal progress, professional ability development and promotion speed, respectively. In this study, the reliability estimates for the subscales were $0.87,0.87$ and 0.82 . The unidimensionality of each subscale was confirmed using the eigenvalues-greater-than-unit rule, with factor loadings between 0.61 and 0.85 .

Intention to quit was measured using two items derived from the Turnover Intention Scale developed by Roodt (2004). The two items were utilised in this study because they directly reflected the actual ITQ construct, whilst the rest of the items represented several push and pull factors explaining why a person may want to quit. In the current study, the Cronbach's alpha for the two items was 0.72 .

Indicator variables were created from each scale to represent the latent variables in order to evaluate the measurement and structural models with LInear Structural RELations (LISREL) 8.8. For the three multidimensional scales, the subscales averages were used as item parcels, and for the unidimensional scales, two item parcels per latent variable were created by averaging the even numbered and uneven numbered items, respectively. In the case of ITQ, the two individual items served as manifest indicators.

\section{Research procedure and ethical considerations}

The inclusion criteria for the study were artisans that are in possession of a trade test certificate in millwright, electrician, plumber, boilermaker, mechanic, fitter and turner, pattern maker or injection moulder and engineers who hold a recognised and accredited qualification that can be the basis for registration with the Engineering Council of South Africa. Briefing sessions were held with potential participants in the workshops where they were based. The purpose of these briefing sessions was to explain the purpose of the study, confidentiality and to recruit the participants who were willing to participate. The participants were assured of the voluntary nature of their participation, and that they could withdraw at any time during the study. The researcher booked a boardroom for each session so that the employees who were willing to participate could complete the questionnaire in a controlled environment. Participants were required to sign an informed consent form.

There was a collection box that was placed in the boardroom so that once the participant had completed the questionnaire, they could drop their completed questionnaire in the box. This was done to guarantee the anonymity of the responses of the participants.

\section{Statistical analysis}

The data yielded 238 cases of which 233 were complete cases without any missing values, whilst five cases had missing values. The imputation by matching procedure was used to deal with the aforementioned cases with missing values. This procedure allows for the substitution of missing values with real values, derived from other cases with similar response patterns over a set of matching variables (Jöreskog \& Sörbom, 1999). 
As part of the preliminary analyses, the reliability estimates of the individual scales were calculated and the unidimensionality of the scales or subscales was confirmed. This was followed by evaluating the overall measurement model with confirmatory factor analysis to test how well the measured variables represented the constructs. Acceptable results for the measurement model in terms of the fit statistics and factor loadings are considered a prerequisite for evaluating the structural model and consequently for interpreting the path coefficients representing the statistical hypotheses (Hair, Black, Babin, \& Anderson, 2014a).

Robust maximum likelihood estimation method was used to produce estimates for the measurement and structural models. In evaluating the measurement and structural model fit, the following fit indices were utilised: root mean square error of approximation (RMSEA), goodness-of-fit (GFI), normed fit index (NFI) and non-normed fit index (NNFI), comparative fit index (CFI) and standardised root mean square residual (SRMR). The RMSEA, GFI and SRMR are absolute fit indices and the NFI, NNFI and CFI are incremental fit indices (Hair et al., 2014a). The absolute fit indices indicate the accuracy with which the specified model reproduces the observed sample covariance matrix, whilst the incremental fit indices evaluate how well the estimated model fits relative to an alternative baseline model. Moreover, whilst high values are indicative of good fit for the GFI, NFI, NNFI and CFI, the opposite is true for the RMSEA and SRMR - the reason being that as these two measures (sometimes referred to as 'badness-of-fit' measures) examine the discrepancies between the reproduced model and observed data, low values suggest a good fit. Root mean square error of approximation values of up to 0.05 indicate a good model fit, whilst values of up to 0.08 indicate a reasonable model fit, and values between 0.08 and 0.10 suggest a mediocre fit (MacCallum, Browne, \& Sugawara, 1996). In addition, a non-significant $p$-value (> 0.05) for the obtained RMSEA value indicates that the null hypothesis stating that the model has close, albeit imperfect fit in the population $\left(\mathrm{H}_{0}\right.$ : $\left.\mathrm{RMSEA}<0.05\right)$ cannot be rejected. For the SRMR, values below 0.08 demonstrate a good fit (Hu \& Bentler, 1999). In terms of the GFI, NFI, NNFI and CFI, values of 0.90 and higher are considered indicative of good fit (Diamantopoulos \& Siguaw, 2000) although $\mathrm{Hu}$ and Bentler (1999) suggest cut-off values of 0.95 .

\section{Ethical considerations}

This study was approved by the Research Ethics Committee (Human Research) at Stellenbosch University (REC-050411-032).

\section{Results \\ Testing of the measurement model}

The unidimensionality of the individual scales (or subscales in the case of multiple scales) was confirmed and all scales yielded satisfactory alpha coefficients (reported under the measuring instruments section). The overall measurement model demonstrated a good fit to the data with RMSEA = 0.0531 and its $p$ value 0.335 , indicating that the hypothesis of close fit $\left(\mathrm{H}_{0}: \mathrm{RMSEA} \leq 0.05\right)$ cannot be rejected. The other fit indices also suggested a good model fit $(\mathrm{GFI}=0.909, \mathrm{NFI}=$ $0.976, \mathrm{NNFI}=0.987, \mathrm{CFI}=0.990$ and $\mathrm{SRMR}=0.052$ ). Moreover, inspection of the parameter estimates revealed that all indicators loaded significantly onto the latent variables they were tasked to reflect, supporting the measurement model's adequacy. This gave justification for evaluating the structural model and the relationships specified thereof.

\section{Testing of the research model}

Table 1 indicates the fit indices for the hypothesised structural model. The RMSEA value of 0.066 demonstrated a reasonable fit, but the hypothesis of close fit was rejected as indicated by the significant $p$-value associated with the test for close fit (0.011). The rejection of the hypothesis of close fit is not ideal, but the interpretation of the other GFI indices discussed here demonstrated that the structural model fitted the data reasonably with NFI (0.969), NNFI (0.979) and CFI (0.984). The GFI value of 0.883 marginally missed the 0.90 recommended cut-off value, but overall the results seemed reasonable.

Whilst the original structural model seemed satisfactory, it was decided to inspect the modification indices (MI) to guide in the development of alternative theory-based models. Large modification indices $(>6.64$ ) are indicative of the parameters that, if set free, lead to significant improvement of model fit (Jöreskog \& Sörbom, 1999). Consideration of modification indices is recommended only if such modifications make substantive and theoretical sense (Diamantopoulos \& Siguaw, 2000). Inspection of the modification indices suggested two additional paths that could improve model fit and which could also be substantiated theoretically: a direct path from perceived organisational justice to ITQ (modification index value 7.57) and a path from perceived organisational support to satisfaction with pay (modification index value 66.97).

With regard to the path between perceived organisational justice and ITQ, equity theory states (Adams, 1963) that when people perceive inequity between their output-input ratio and that of referent others, they attempt to restore equity and

TABLE 1: Goodness of fit indices for the original and modified structural models.

\begin{tabular}{lccccccccc}
\hline Fit statistics & df & S-B $\chi^{2}$ & RMSEA & $p_{\text {close fit }}$ & SRMR & GFI & NFI & NNFI & CFI \\
\hline Original Structural model & 134 & 272.771 & 0.066 & 0.011 & 0.061 & 0.883 & 0.969 \\
Modified Structural model & 132 & 227.632 & 0.055 & 0.229 & 0.058 & 0.901 & 0.974 & 0.985 \\
\hline
\end{tabular}

S-B $\chi^{2}$, Satorra-Bentler chi-square; RMSEA, root mean square error of approximation; SRMR, standardised root mean square residual; GFI, goodness-of-fit index; NFI, normed fit index; NNFI, non-normed fit index; $\mathrm{CFI}$, comparative fit index. 


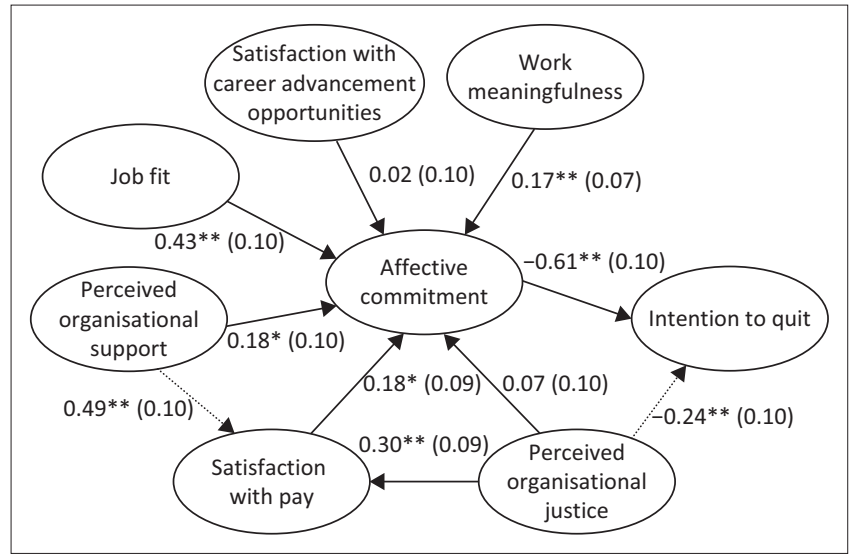

Standard errors are included in parentheses. Solid lines represent the original model and dotted lines represent the additional paths specified in the modified model.

$*, p<0.05$, one-tailed; $* *, p<0.01$, one-tailed.

FIGURE 2: Standardised coefficients for final integrated model of ITQ amongst artisans and engineers.

if this is not attained they remove themselves from the situation (Pritchard, 1969). Turnover intentions have, therefore, been reported to be high when distributive, procedural and interpersonal justice perceptions are low (Siers, 2007). The path from perceived organisational support to satisfaction with pay can be explained theoretically in that perceived organisational support may be viewed as a nonmonetary reward that an organisation offers to its employees. For example, organisational support can be rendered in the form of providing artisans and engineers with adequate tools and resources to do their work effectively, training and developing them to increase their employability, designing their jobs to be more favourable or flexible to the individual (Schlechter et al., 2014) or increasing opportunities for social interaction. According to discrepancy theory, this may decrease the amount that employees believe they should receive (or increase the amount that they perceive they are receiving) and subsequently improve equity perceptions (Shapiro \& Wahba, 1978). Note that it is not necessarily that with which the employee is supported, which is the decisive factor, but rather it is the overall perception that they are being cared for and their interests are being looked after by the organisation, which provides a sense of contentment with pay. The modified structural model with the inclusion of the aforementioned paths and standardised path loadings are presented in Figure 2.

The modified model was subsequently compared with the original model following the guidelines by Bryant and Satorra (2012) for testing chi-square differences with continuous non-normal data. The decrease in the SatorraBentler chi-square $(2, N=238)=43.156$ brought about by the addition of the two extra paths was statistically significant $(p<0.01)$. Inspection of the fit indices of the modified model corroborated the improvement in model fit: GFI (0.90), NFI (0.97), NNFI (0.98) and CFI (0.98) (see Table 1 for a comparison between the models). Furthermore, the results show that the modified structural model obtained an RMSEA value of 0.055 and an SRMR value of 0.058 , which are indicative of good model fit. Finally, the hypothesis of close fit was not rejected as indicated by the non-significant $p$-value associated with the test for close fit (0.229). It was consequently decided to interpret the parameter estimates of the modified model. Table 1 shows how the models compare in terms of the aforementioned fit indices.

\section{Relationships between latent variables}

Figure 2 depicts the standardised parameter estimates for the hypothesised relationships between the latent variables. Strong support was found for the negative relationship between affective commitment and ITQ $(H 1: \beta$ $=-0.61, p<0.01)$, confirming that affective commitment is indeed a key proximal antecedent of ITQ. Of the six constructs hypothesised to influence affective commitment, all the structural path estimates were in the expected direction, but two of the paths ( $\mathrm{H} 2$ and $\mathrm{H} 7)$ did not reach statistical significance at the 5\% significance level (onetailed, critical $t$-value: $|1.65|$ ) and therefore the null hypotheses could not be rejected for $\mathrm{H} 2$ and H7. (Hair, Hult, Ringle, \& Sarstedt, 2014b). From this it can be concluded that neither perceived organisational justice $(H 2: \beta=0.07, n s)$ nor satisfaction with career advancement opportunities $(H 7: \beta=0.02, n s)$ had a significant relationship with affective commitment in the current model, that is, with all other predictors of affective commitment held constant. With regard to the other four constructs hypothesised to influence affective commitment, the data provided support that each predictor contributed to the explanatory variance in affective commitment: satisfaction with pay (H3: $\beta=0.18, p<0.05)$, perceived organisational support $(H 5: \beta=0.18, p<0.05)$, job fit $(H 6: \beta=0.43, p<0.01)$ and meaningful work $(H 8: \beta=0.17, p<0.01)$.

Moreover, the results revealed that each of the four aforementioned constructs had an indirect effect on ITQ via their influence on affective commitment. This was tested by inspection of the critical values ( $t$-values: $|1.65|$ for $5 \%$ level of significance under one-tailed hypothesis) accompanying the product of the unstandardised parameter estimates of the intervening variables as produced in LISREL 8.8 (Diamantopoulos \& Siguaw, 2000; Hair et al., 2014b). The $t$-values for the indirect effect of the four predictors on ITQ were as follows: satisfaction with pay $(t=-1.95, p<0.05)$, perceived organisational support $(t=-2.59, p<0.01)$, job fit $(t=-3.62, p<0.01)$ and meaningful work $(t=-2.54, p<0.01)$.

This further confirmed the central role of affective commitment in reducing ITQ.

The results also supported the hypothesised relationship between perceived organisational justice and satisfaction with pay ( $H 4$ : $\beta=0.30, p<0.01$ ), suggesting that although perceived organisational justice does not show a direct relationship with affective commitment, it potentially influences affective commitment via its effect on satisfaction with pay. Partial support for the indirect effect was also confirmed by the accompanying $t$-value (1.65), interpreted as explained above. 
Finally, the two additional paths added to the model proved to be statistically significant, with the results revealing a negative relationship between perceived organisational justice and ITQ $(\beta=-0.24, p<0.01)$, as well as between perceived organisational support and satisfaction with pay ( $\beta=0.49, p<0.01)$. Overall, the structural model explained $59.4 \%$ of the variance in ITQ and $72.6 \%$ in affective commitment.

The model thus indicates a reasonably successful attempt to explain variance in the two key target variables.

\section{Discussion}

\section{Outline of the results}

This study sought to validate a theoretical model that explicates the antecedents of affective commitment and the impact thereof on ITQ. The validation of the structural model entailed the evaluation of the measurement and structural model and an assessment of whether the theoretical relationships specified in the structural model were supported by the data. The potential contribution of the study pertains to identifying variables that positively influence affective commitment and empirically establish the central role played by affective commitment in the retention of artisans and engineers.

The evaluation of the fit indices indicated a good fit of the measurement model, which confirmed that the composite indicators reflected the latent variables they were tasked to reflect. The evaluation of the original structural model indicated that the structural model demonstrated a reasonable fit although the hypothesis of close fit was rejected. Inspection of the modification indices indicated that the addition of two paths would improve model fit and because these paths could be theoretically justified, the model was modified accordingly. The modified structural model indicated a good fit and eight of the 10 specified structural paths in the model were found to be statistically significant.

Affective commitment was found to have a strong significant negative relationship with ITQ of artisans and engineers. This finding is consistent with other research findings that show the explanatory potential of affective commitment for employee retention (Delobbe \& Vandenberghe, 2000; Dockel, Basson, \& Coetzee, 2006; Fazio et al., 2017; Griffeth et al., 2000; Saleem \& Qamar, 2017; Sun, 2011). The results also corroborate previous findings that show that job fit (Kooij \& Boon, 2018; Kristof-Brown et al., 2005), psychological meaningfulness (Geldenhuys, Łaba, \& Venter, 2014; Jiang \& Johnson, 2018), perceived organisational support (Rhoades et al., 2001; Wong $\&$ Wong, 2017) and satisfaction with pay (Coetzee et al., 2014; Jordaan \& Barry, 2009; Panaccio et al., 2014; Schlechter et al., 2014; Sun, 2011; Van Rooyen et al., 2010) are positively related to affective commitment. Also of note is the indirect effect of these constructs on ITQ via its effect on affective commitment. These findings substantiate the central role played by affective commitment in the retention of artisans and engineers. This suggests that organisations will be more successful in facilitating affective commitment, and such reduce ITQ, when they create meaningful work; pay competitive remuneration; show that they really care about their workforce; and match the competencies, skills and abilities of employees with their roles.

Although perceived organisational justice did not show a significant relationship with affective commitment (contradicting the findings of some earlier studies, for instance, Colquitt et al., 2001), the data revealed a direct effect on ITQ. This suggests that perceived organisational justice does not necessarily facilitate emotional ties with the organisation (affective commitment); nonetheless, when inequity is perceived, people are more likely to become dissatisfied and leave the organisation. According to this line of reasoning, perceived organisational justice is critical for retaining employees, but on its own is unlikely to create an engaged, committed workforce - thus functioning to some extent as a hygiene factor (Sachau, 2007; Woods \& West, 2014). Partial support for the effect of perceived organisational justice on affective commitment can, however, be found via its relationship with satisfaction with pay.

As explained earlier, to facilitate an engaged, committed workforce, organisations need to pay attention to job fit, perceived organisational support, meaningful work and satisfaction with pay. Of these four, job fit had the strongest relationship with affective commitment, emphasising the important role of human resource practices promoting work adjustment and integration in the work environment (Boon, Den Hartog, Boselie, \& Paauwe, 2011; Dawis \& Lofquist, 1978; Kristof-Brown et al., 2005). Moreover, the fact that job fit had such a strong relationship with affective commitment, whilst the effect of satisfaction with career advancement opportunities was insignificant, suggests that for specialists, such as artisans and engineers, being able to express themselves through their skills, competencies and values is of more importance than lateral promotions. From a human resource perspective, this highlights the importance of skill-based job evaluation systems for specialist jobs where people are rewarded for learning new skills, rather than for moving up the corporate ladder (Noe, Hollenbeck, Gerhart, \& Wright, 2012).

The lack of support for the positive relationship between satisfaction with career development and advancement opportunities contradicts previous research findings (Coetzee et al., 2014; Sturges, Conway, Guest, \& Liefooghe, 2005; Weng et al., 2010).

The positive relationship between perceived organisational support and satisfaction with pay is a somewhat unexpected finding that shows the impact of organisational support on people's appraisal of the rewards they receive. As explained earlier, people's expectancy of what they believe they should receive can be reduced by providing them with valuable, non-monetary rewards (Schlechter et al., 2014; Shapiro \& 
Wahba, 1978). To put it in slightly different terms, it can be argued that people are more tolerant of relatively lower salaries when they perceive the company to have their best interest in mind. It is also interesting to note that the effect of perceived organisational support on satisfaction with pay was larger than that of perceived organisational justice. Again, this emphasises that companies should not only convey the message that they are fair in their dealings with employees, but that they genuinely care about each individual by how they recognise and reward employees. It must be stated that conveying the message that the organisation genuinely cares does not necessarily imply paying higher or unsustainable salaries; rather it speaks of a supportive management (Bussin et al., 2019) that provides recognition and security to employees within current constraints. This matter seems especially important at the time of writing this article, that is, during the 2020 the coronavirus disease 2019 (Covid-19) lockdown, with employees anxious about their physical safety and job security. Wang, Ma, Liu and Liu (2014) explained that:

[I]f employees perceive the organisation as willing to provide job security, they tend to regard the organisation as responsible and supportive and, in turn, engage in behaviour supporting organisational goals. (p. 1070)

\section{Practical implications}

This study reported a strong negative relationship between affective commitment and ITQ.

It also confirmed the central role of affective commitment as a mediator through which various job and organisational characteristics influence turnover intentions. This suggests that organisations that are serious about the retention of artisans and engineers should ensure that their human resource management interventions contribute to affective commitment. By measuring affective commitment on an ongoing basis, for example, organisations will be able to evaluate the impact of their interventions. Moreover, knowledge about the level of affective commitment will enable organisations to predict future turnover and act proactively.

According to the findings of this study, affective commitment can be fostered through focusing on job fit, providing meaningful work, demonstrating that the organisation cares and values its employees and providing competitive and market-related salaries. Job fit in particular was highlighted as very important within the sample group. Jobs and organisational cultures should therefore be designed with consideration of the unique needs and values expressed by artisans and engineers. For example, since artisans and engineers are specialists, it will be important for them to apply their technical skills and expertise and also receive recognition in this area.

The results further indicated that perceived organisational support is important for experiencing pay satisfaction, even more so than perceived organisational justice. This implies that the relationship between the employer and employee should be more than purely transactional where the artisan and engineers are paid high salaries to get the work done without feeling cared for or valued by the organisation. Special consideration should therefore be given to conveying a message of support to artisans and engineers. One way to do this is through supportive management (Bussin et al., 2019) and non-monetary rewards such a work-life balance policies (Nujjoo \& Meyer, 2012; Schlechter et al., 2014). Notwithstanding the need to emphasise non-monetary rewards, it would be futile to design rewards system without consideration of salary levels. A recent study among Generation Y employee in South Africa reveals that salary levels remain a key consideration for the younger generation (Bussin et al., 2019).

The results also yielded a direct negative relationship between perceived organisational justice and ITQ. Organisations should ensure that their policies, procedures, structures and systems are fair, just and promote trust and mutual respect (Colquitt \& Rodell, 2011). One particular sensitive and challenging issue is that of employment equity, a transformation process of redressing past injustices in South Africa. Previous studies have indicated that employment equity policies, related to career advancement opportunities and increased pay, are often perceived as unfair by some artisans and engineers, contributing not only to low commitment but also to decisions to emigrate (Du Toit \& Roodt, 2009; Mukora, 2009; Van Rooyen et al., 2010). Whilst employment equity is important for social justice and developing a more representative workforce, organisations should be careful not to apply it in a rigid manner, focusing only on getting the numbers right. Valid and reliable procedures should be used for selection and promotion decisions and where people are not promoted because of equity reasons, alternative ways should be sought to recognise and reward their contributions to their organisations (Schlechter et al., 2014).

\section{Limitations and suggestions for future research}

Although this study yielded informative and insightful findings, it had some limitations. The study utilised the ex post facto research design that is cross-sectional in nature, hence the findings in this study do not prove causality between the exogenous and endogenous variables of interest. Nonetheless, when relationships between latent variables are grounded in theoretical understandings that explain the causal mechanism, path estimates in structural equation modelling (SEM) might be interpreted as yielding evidence of relationships believed to be consistent with causal relationship (Bagozzi \& Yi, 2012; Spector, 2019; Weston \& Gore, 2006). To increase claims of causality, future studies can use longitudinal studies and, where feasible, experimental designs (Bagozzi \& Yi, 2012; Kerlinger \& Lee, 1964).

A related concern is that self-report surveys may be subject to common method bias. This refers to the situation where there is an appearance of a relationship between variables, which 
in reality is the result of the method used to measure the constructs (Podsakoff, MacKenzie, Lee, \& Podsakoff, 2003). Specifically, common rater effect occurs when the participants are asked to rate themselves on all the constructs without objective measures, additional source of measurement or time delays in measurement. The risk of common method, however, is somewhat less pertinent when there is no need to respond in a socially desirable manner as in this study. Also, the study aimed to control common method bias through the careful selection and design of scale items, including using structural equation modelling which to some extent accounts for measurement error (Podsakoff et al., 2003).

Furthermore, Siemsen, Roth and Oliveira (2010) observed that common method bias can actually decrease, rather than inflate, regression estimates in multivariate linear relationships because of a larger number of measured variables suffering from common method bias in the estimation.

Another limitation is the lack of generalisability of the study findings to the broader population of artisans and engineers. The sample used in this study was drawn from a single large manufacturing and engineering organisation, which limits generalisability across different industries and business sectors. Notwithstanding the need for ongoing studies with different samples from different industrial sectors (Landy \& Conte, 2013), reflecting on previous studies conducted in South Africa and internationally suggests that the findings converge with previous research, giving credence to the external validity of the study findings.

Furthermore, the sample was male-dominated (91.6\%). The findings presented are therefore not necessarily representative of female participants. More research is required to investigate the factors influencing female artisans and engineers. For example, a study by Bussin et al. (2019) among knowledge workers revealed that gender can significantly impact salary and reward preference.

The current study did not include variables that characterise the external labour market and employee's perceptions of these characteristics. Variables such as perceived alternative opportunities, perceived utility movement and perceived human capital are some of the useful external employment market variables that have been reported to be important in understanding turnover cognitions (Griffeth et al., 2000; Saleem \& Qamar, 2017).

The current study only focused on one form of organisational commitment, namely, affective commitment. Although, as explained earlier, affective commitment has consistently shown to be the strongest form of commitment (Meyer et al., 2002) and is also related to various pro-social and organisational citizenship behaviours (Chênevert et al., 2015), the two other forms of commitment included in Meyer and Allen's (1991) three-component model (i.e. continuance and normative commitment) could further enhance our understanding of employees' reasons for leaving their organisations. Moreover, by knowing which antecedents are related to what type or kind of commitment, human resource practitioners will be empowered to design interventions that will influence the desired commitment.

Finally, the current study tested a structural model of artisan and engineer turnover intention. The conceptualisation of the structural model was informed by various studies about intention to quit and affective commitment in general, but also contextual studies focussing on artisans and engineers. In terms of the latter, qualitative studies have provided greater understanding of the variables and how they relate. In turn, the current study gives empirical credence to propositions and hypotheses emanating from these qualitative work. A logical next step would now be to return to the qualitative phase to obtain a more in-depth understanding of the various interrelated facets in the structural model (Landy \& Conte, 2013); with emphasis on how each variable needs to be construed to further the engagement and retention of artisans and engineers in South Africa. For example, job fit was found to be a critical factor in the research, suggesting that jobs and organisational cultures should be designed with consideration of the unique needs and values expressed by artisans and engineers. Follow-up qualitative studies could, for example, investigate the exact nature of these unique needs and values.

\section{Conclusion}

Retention of highly skilled and experienced artisans and engineers is a key challenge for organisations in South Africa. This study suggests that affective commitment and perceived organisational justice are strong predictors of intention to stay. For organisations to effectively influence affective commitment they should focus on providing competitive and market-related remuneration, meaningful work, organisational support and job design to enhance job fit. They should also ensure that their processes, procedures, policies, systems and structures are fair and just because perceived organisational justice lowers ITQ. Positively influencing affective commitment and perceived organisational justice will result in the retention of artisans and engineers.

\section{Acknowledgements Competing interests}

The authors have declared that no competing interests exist.

\section{Authors' contributions}

S.W. was responsible for the theoretical development of the model, data collection, analysis and interpretation, and writing of the journal article. F.V.D.B was the project supervisor and was responsible for the project design, data analysis and interpretation, and writing of the article.

\section{Funding information}

This research received no specific grant from any funding agency in the public, commercial or not-for-profit sectors. 


\section{Data availability}

The data that support the findings of this study are available from the corresponding author (S.S.) upon reasonable request.

\section{Disclaimer}

The views and opinions expressed in this article are those of the authors and do not necessarily reflect the official policy or position of any affiliated agency of the authors.

\section{References}

Adams, J.S. (1963). Towards an understanding of inequity. The Journal of Abnormal and Social Psychology, 67(5), 422. https://doi.org/10.1037/h0040968

Addae, H.M., Parboteeah, K.P., \& Davis, E.E. (2006). Organizational commitment and intentions to quit. International Journal of Organizational Analysis, 14(3), 225-238. https://doi.org/10.1108/19348830610823419

Arnold, T., \& Spell, C.S. (2006). The relationship between justice and benefits satisfaction. Journal of Business and Psychology, 20(4), 599-620. https://doi. org/10.1007/s10869-005-9006-1

Arthur, M.B. (2014). The boundaryless career at 20: Where do we stand, and where can we go? Career Development International, 19(6), 627-640. https://doi. can we go? Career Developm
org/10.1108/CDI-05-2014-0068

Atkinson, J.W. (1964). An introduction to motivation. Oxford: Van Nostrand.

Bagozzi, R.P., \& Yi, Y. (2012). Specification, evaluation, and interpretation of structura equation models. Journal of the Academy of Marketing Science, 40(1), 8-34. https://doi.org/10.1007/s11747-011-0278-x

Bailey, C., Yeoman, R., Madden, A., Thompson, M., \& Kerridge, G. (2019). A review of the empirical literature on meaningful work: Progress and research agenda. Human Resource Development Review, 18(1), 83-113. https://doi.org/10.1177/ 1534484318804653

Baruch, Y. (2004). Transforming careers: From linear to multidirectional career paths: Organizational and individual perspectives. Career Development International, 9(1), 58-73. https://doi.org/10.1108/13620430410518147

Beechler, S., \& Woodward, I.C. (2009). The global 'war for talent'. Journal of International Management, 15(3), 273-285. https://doi.org/10.1016/j.intman. 2009.01.002

Boon, C., Den Hartog, D.N., Boselie, P., \& Paauwe, J. (2011). The relationship between perceptions of HR practices and employee outcomes: Examining the role of person-organisation and person-job fit. The International Journal of Human Resource Management, 22(01), 138-162. https://doi.org/10.1080/09585192.201 1.538978

Bothma, C.F.C., \& Roodt, G. (2013). The validation of the turnover intention scale. SA Journal of Human Resource Management, 11(1), 1-12. https://doi.org/10.4102/ sajhrm.v11i1.507

Breier, M. (2009). Introduction. In J. Erasmus \& M. Breier (Eds.), Skills shortages in South Africa: Case studies of key professionals (pp. 1-21). Cape Town: Human Sciences Research Council Press.

Bryant, F.B., \& Satorra, A. (2012). Principles and practice of scaled difference chisquare testing. Structural Equation Modeling: A Multidisciplinary Journal, 19(3), 372-398. https://doi.org/10.1080/10705511.2012.687671

Bussin, M.H.R., \& Brigman, N. (2019). Evaluation of remuneration preferences of knowledge workers. SA Journal of Human Resource Management, 17(1), 1-10.

Bussin, M.H.R., Mohamed-Padayachee, K., \& Serumaga-Zake, P. (2019). A total rewards framework for the attraction of Generation Y employees born 1981-2000 in South Africa. SA Journal of Human Resource Management, 17(1), 1-14.

Chalofsky, N., \& Krishna, V. (2009). Meaningfulness, commitment, and engagement The intersection of a deeper level of intrinsic motivation. Advances in Developing Human Resources, 11(2), 189-203. https://doi.org/10.1177/1523422309333147

Chênevert, D., Vandenberghe, C., \& Tremblay, M. (2015). Multiple sources of support, affective commitment, and citizenship behaviors. Personnel Review, 44(1), 69-90. https://doi.org/10.1108/PR-08-2012-0144

Coetzee, M., Mitonga-Monga, J., \& Swart, B. (2014). Human resource practices as predictors of engineering staff's organisational commitment. South African
Journal of Human Resource Management, 12(1), 1-9. https://doi.org/10.4102/ sajhrm.v12i1.604

Cohen-Charash, Y., \& Spector, P.E. (2001). The role of justice in organizations: A metaanalysis. Organizational Behavior and Human Decision Processes, 86(2), 278-321. https://doi.org/10.1006/obhd.2001.2958

Cole, M.S., Bernerth, J.B., Walter, F., \& Holt, D.T. (2010). Organizational justice and individuals' withdrawal: Unlocking the influence of emotional exhaustion. Journal of Management Studies, 47(3), 367-390.

Colquitt, J.A. (2001). On the dimensionality of organizational justice: A construct validation of a measure. Journal of Applied Psychology, 86(3), 386. https://doi. org/10.1037/0021-9010.86.3.386

Colquitt, J.A., \& Rodell, J.B. (2011). Justice, trust, and trustworthiness: A longitudinal analysis integrating three theoretical perspectives. Academy of Management analysis integrating three theoretical perspectives. Academy of
Journal, 54(6), 1183-1206. https://doi.org/10.5465/amj.2007.0572
Colquitt, J.A., Conlon, D.E., Wesson, M.J., Porter, C.O.L.H., \& Ng, K.Y. (2001). Justice at the millennium: A meta-analytic review of 25 years of organizational justice research. Journal of Applied Psychology, 86(3), 425. https://doi.org/10.1037/0021research. Journ

Dawis, R., \& Lofquist, L.H. (1978). A note on the dynamics of work adjustment. Journal of Vocational Behavior, 12(1), 76-79. https://doi.org/10.1016/0001-8791(78) 90008-8

Delobbe, N., \& Vandenberghe, C. (2000). A four-dimensional model of organizational commitment among Belgian employees. European Journal of Psychological Assessment, 16(2), 125. https://doi.org/10.1027//1015-5759.16.2.125

Department of Higher Education and Training. (2018). Skills Development Act No. 97 of 1998: Draft National Artisan Development Strategy and Implementation Plan 2017. Government Gazette No. 41704, Pretoria: Government Printing Works.

Department of Higher Education and Training. (2020). List of occupations in high demand draft 2020. Government Gazette No. 43621, Pretoria: Government Printing Works.

Diamantopoulos, A., \& Siguaw, J.A. (2000). Introducing LISREL. London: Sage.

Dockel, A., Basson, J.S., \& Coetzee, M. (2006). The effect of retention factors on organisational commitment: An investigation of high technology employees. SA Journal of Human Resource Management, 4(2), 20-28. https://doi.org/10.4102/ sajhrm.v4i2.91

Dulebohn, J.H., \& Werling, S.E. (2007). Compensation research past, present, and future. Human Resource Management Review, 17(2), 1919-207. https://doi org/10.1016/j.hrmr.2008.10.001

Dulebohn, J.H., Molloy, J.C., Pichler, S.M., \& Murray, B. (2009). Employee benefits: Literature review and emerging issues. Human Resource Management Review, 19(2), 86-103. https://doi.org/10.1016/j.hrmr.2008.10.001

Du Toit, R., \& Roodt, J. (2009). Engineering professionals. In J. Erasmus \& M. Breier (Eds.), Skills shortages in South Africa: Case studies of key professionals (pp. 75-112). Human Sciences Research Council Press. Retrieved from http://hdl. handle.net/20.500.11910/4717

Edwards, J.R. (1991). Peson-job fit: A conceptual intergration, literature review and methodological critique. In C. L. Cooper \& I. T. Robertson (Eds.), International review of industrial and organizational psychology (pp. 238-357). Oxford: John review of industr

Fazio, J., Gong, B., Sims, R., \& Yurova, Y. (2017). The role of affective commitment in the relationship between social support and turnover intention. Management Decision, 55(3), 512-525. https://doi.org/10.1108/MD-05-2016-0338

Ferreira, N., Coetzee, M., \& Masenge, A. (2013). Psychological career resources, career adaptability and hardiness in relation to job embeddedness and organizational commitment. Journal of Psychology in Africa, 23(1), 31-40. https:// doi.org/10.1080/14330237.2013.10820591

Firth, L., Mellor, D.J., Moore, K.A., \& Loquet, C. (2004). How can managers reduce employee intention to quit? Journal of Managerial Psychology, 19(2), 170-187. https://doi.org/10.1108/02683940410526127

Fishbein, M., \& Ajzen, I. (1975). Belief, attitudes, intention and behavior. Massachusetts: Addison-Wesley.

Fletcher, L. (2016). How can personal development lead to increased engagement? The roles of meaningfulness and perceived line manager relations. The International Journal of Human Resource Management, 30(7), 1203-1226. https://doi.org/10.1080/09585192.2016.1184177

Fong, S., \& Shaffer, M. (2003). The dimensionality and determinants of pay satisfaction: A cross-cultural investigation of a group incentive plan. International Journal of Human Resource Management, 14(4), 559-580. https://doi.org/10.1080/ of Human Resource Nan

Geldenhuys, M., Łaba, K., \& Venter, C.M. (2014). Meaningful work, work engagement and organisational commitment. SA Journal of Industrial Psychology, 4O(1), 1-10. https://doi.org/10.4102/sajip.v40i1.1098

Gow, K., Warren, C., Anthony, D., \& Hinschen, C. (2008). Retention and intentions to quit among Australian male apprentices. Education and Training, 50(3), 216-230. https://doi.org/10.1108/00400910810873991

Griffeth, R.W., Hom, P.W., \& Gaertner, S. (2000). A meta-analysis of antecedents and correlates of employee turnover: Update, moderator tests, and research implications for the next millennium. Journal of Management, 26(3), 463-488. https://doi.org/10.1177/014920630002600305

Hackman, J.R., \& Oldham, G.R. (1976). Motivation through the design of work: Test of a theory. Organizational Behavior and Human Performance, 16(2), 250-279. https://doi.org/10.1016/0030-5073(76)90016-7

Hair, J.F., Black, W.C., Babin, B.J., \& Anderson, R.E. (2014a). Multivariate data analysis (7th edn.). Harlow: Pearson.

Hair, J.F., Hult, G.T.M., Ringle, C.M., \& Sarstedt, M. (2014b). A primer on partial least squares structural equation modeling (PLS-SEM). Los Angeles: Sage.

Haynie, J.J., Svyantek, D.J., Mazzei, M.J., Varma, V., Adcroft, A., \& Murphy, P. (2016). Job insecurity and compensation evaluations: The role of overall justice. Management Decision, 54(3), 630-645. https://doi.org/10.1108/MD-04-20150134

Heneman, III. H.G., \& Schwab, D.P. (1985). Pay satisfaction: Its multidimensional nature and measurement. International Journal of Psychology, 20(1), 129-141. https://doi.org/10.1080/00207598508246743

Hirschi, A. (2018). The fourth industrial revolution: Issues and implications for career research and practice. Career Development Quarterly, 66(3), 192-204. https:// doi.org/10.1002/cdq.12142

Holtom, B.C., Lee, T.W., \& Tidd, S.T. (2002). The relationship between work status congruence and work-related attitudes and behaviors. Journal of Applied Psychology, 87(5), 903. https://doi.org/10.1037/0021-9010.87.5.903 
Hom, P.W., Tsui, A.S., Wu, J.B., Lee, T.W., Zhang, A.Y., Fu, P.P., \& Li, L. (2009). Explaining employment relationships with social exchange and job embeddedness. Journal employment relationships with social exchange and job embeddedn
of Applied Psychology, 94(2), 277. https://doi.org/10.1037/a0013453

Hu, L., \& Bentler, P.M. (1999). Cutoff criteria for fit indexes in covariance structure analysis: Conventional criteria versus new alternatives. Structural Equation Modeling: A Multidisciplinary Journal, 6(1), 1-55. https://doi.org/10.1080/ 10705519909540118

Ilies, R., Lanaj, K., Pluut, H., \& Goh, Z. (2018). Intrapersonal and interpersonal need fulfillment at work: Differential antecedents and incremental validity in explainin job satisfaction and citizenship behavior. Journal of Vocational Behavior, 108, 151-164. https://doi.org/10.1016/j.jvb.2018.07.005

Jiang, L., \& Johnson, M.J. (2018). Meaningful work and affective commitment: A moderated mediation model of positive work reflection and work centrality Journal of Business and Psychology, 33(4), 545-558. https://doi.org/10.1007/ s10869-017-9509-6

Joint Initiative on Priority Skills Acquisition. (2010). Growing priority skills in South Africa final report on JIPSA. Republic of South Africa. Retrieved from https:// hrdcsa.org.za/wp-content/uploads/research-reports/Consolidated\%20JIPSA\%20 hrdcsa.org.za/wp-content/uploac
close\%20out\%20report_0.pdf

Jordaan, N., \& Barry, M.-L. (2009). Investigating the reasons for lack of skilled artisans in South Africa: The perspective of artisans. South African Journal of Industria Engineering, 20(1), 173-184.

Jöreskog, K., \& Sörbom, D. (1999). PRELIS 2: User's reference guide (version 8.80). Lincolnwood: Scientific Software International.

Kaye, B., \& Jordan-Evans, S. (2002). Retention tough in times. Training \& Development, $56(1), 32$

Kerlinger, F.N., \& Lee, H.B. (1964). Foundations of behavioural research (4th edn.). London: Harcourt College Publishers.

Kim, B., Rhee, E., Ha, G., Jung, S.H., Cho, D., Lee, H.K., \& Lee, S.M. (2016a). Cross cultural validation of the career growth scale for Korean Employees. Journal of Career Development, 43(1), 26-36. https://doi.org/10.1177/0894845314568310

Kim, K.Y., Eisenberger, R., \& Baik, K. (2016b). Perceived organizational support and affective organizational commitment: Moderating influence of perceived organizational competence. Journal of Organizational Behavior, 37(4), 558-583. https://doi.org/10.1002/job.2081

Kooij, D.T.A.M., \& Boon, C. (2018). Perceptions of HR practices, person-organisation fit, and affective commitment: The moderating role of career stage. Human
Resource Management Journal, 28(1), 61-75. https://doi.org/10.1111/1748Resource
8583.12164

Kristof-Brown, A.L., Zimmerman, R.D., \& Johnson, E.C. (2005). Consequences of individuals' fit at work: A meta-analysis of person-job, person-organization,
person-group, and person-supervisor fit. Personnel Psychology, 58(2), 281-342. https://doi.org/10.1111/j.1744-6570.2005.00672.x

Kuvaas, B. (2006). Work performance, affective commitment, and work motivation: The roles of pay administration and pay level. Journal of Organizational Behavior, 27(3), 365-385. https://doi.org/10.1002/job.377

Landy, F.J., \& Conte, J.M. (2013). Work in the 21th Century: An introduction to industrial and organisational psychology (4th edn.). New York: Wiley.

Latham, G. P., \& Pinder, C. C. (2005). Work motivation theory and research at the dawn of the twenty-first century. Annual Review of Psychology, 56, 485-516. https:// of the twenty-first century. Annual Review of Psych
doi.org/10.1146/annurev.psych.55.090902.142105

Lee, T.W., Hom, P.W., Eberly, M.B., Li, J. (Jason), \& Mitchell, T.R. (2017). On the next decade of research in voluntary employee turnover. Academy of Management Perspectives, 31(3), 201-221.

Local Government Sector Educational and Training Authority. (2016). National enterprise and cooperative development strategy. Retrieved from https://cdn. Igseta.co.za/resources/performance_monitoring_and_reporting_documents/ SMME\%20Research\%2OProject.pdf

Locke, E.A., Mento, A.J., \& Katcher, B.L. (1978). The interaction of ability and motivation in performance: An exploration of the meaning of moderators Personnel Psychology, 31(2), 269-280. https://doi.org/10.1111/j.1744-6570.1978. tb00446.x

Lumley, E.J., Coetzee, M., Tladinyane, R., \& Ferreira, N. (2011). Exploring the job satisfaction and organisational commitment of employees in the information
technology environment. Southern African Business Review, 15(1), 100-118.

MacCallum, R.C., Browne, M.W., \& Sugawara, H.M. (1996). Power analysis and determination of sample size for covariance structure modeling. Psychological Methods, 1(2), 130-149. https://doi.org/10.1037/1082-989X.1.2.130

May, D.R., Gilson, R.L., \& Harter, L.M. (2004). The psychological conditions of meaningfulness, safety and availability and the engagement of the human spirit at work. Journal of Occupational and Organizational Psychology, 77(1), 11-37. https://doi.org/10.1348/096317904322915892

MerSETA. (2018). Promoting artisan development for employability: Sector skills plan update. Retrieved from http://www.merseta.org.za/Announcements\%20Docs/ merSETA\%20Sector\%20Skills\%20Plan\%202019-2020.pdf

Meyer, J.P., \& Allen, N.J. (1991). A three-component conceptualization of organizational commitment. Human Resource Management Review, 1(1), 61-89. https://doi. commitment. Human Resource Man
org/10.1016/1053-4822(91)90011-Z

Meyer, J.P., Stanley, D.J., Herscovitch, L., \& Topolnytsky, L. (2002). Affective, continuance, and normative commitment to the organization: A meta-analysis of antecedents, correlates, and consequences. Journal of Vocational Behavior, 61(1), 20-52. https://doi.org/10.1006/jvbe.2001.1842

Michaels, E., Handfield-Jones, H., \& Axelrod, B. (2001). The war for talent. Boston: Harvard Business Press.

Miceli, M.P., \& Lane, M.C. (1991). Antecedents of pay satisfaction: A review and extension. In K. Rowland \& J. Ferris (Eds.), Research in personnel and human resources management (Vol. 9, pp. 235-309). Greenwich, CT: JAI Press.
Mitchell, T.R., Holtom, B.C., Lee, T.W., Sablynski, C.J., \& Erez, M. (2001). Why people stay: Using job embeddedness to predict voluntary turnover. Academy of Management Journal, 44(6), 1102-1121. https://doi.org/10.2307/3069391

Mobley, W.H., Griffeth, R.W., Hand, H.H., \& Meglino, B.M. (1979). Review and conceptual analysis of the employee turnover process. Psychological Bulletin, 86(3), 493. https://doi.org/10.1037/0033-2909.86.3.493

Mukora, J. (2008). Professions case study report: Artisans. Pretoria: Scare and critical skills research project, Department of Labour.

Mukora, J. (2009). Artisans. In J. Erasmus \& M. Breier (Eds.), Skills shortages in South Africa: Case studies of key professionals (pp. 219-245). Cape Town: Human Sciences Research Council Press.

Mzabalazo advisory services. (2014). Expenditure performance review of the National Artisan Development Programme. Johannesburg: Mzabalazo. Retrieved from https://www.gtac.gov.za/perdetail/20.2\%20Technical\%20report\%20.pdf

Noe, R.A., Hollenbeck, J.R., Gerhart, B., \& Wright, P.M. (2012). Human resource management: Gaining a competitiveness advantage (8th edn.). New York: McGraw-Hill.

Nujjoo, A., \& Meyer, I. (2012). The relative importance of different types of rewards for employee motivation and commitment in South Africa. SA Journal of Human Resource Management, 10(2), 10.

Nyatsumba, K. (2017). South Africa's escalating engineering crisis. Independent Online (IOL) Business Report. Retreived from https://www.iol.co.za/business-report/ south-africas-escalating-engineering-crisis-11670238

O'Driscoll, M.P., \& Randall, D.M. (1999). Perceived organisational support, satisfaction with rewards, and employee job involvement and organisational commitment. Applied Psychology, 48(2), 197-209. https://doi.org/10.1111/j.1464-0597.1999. tb00058.x

O’Reilly, C.A., Chatman, J., \& Caldwell, D.F. (1991). People and organizational culture: A profile comparison approach to assessing person-organization fit. Academy of Management Journal, 34(3), 487-516. https://doi.org/10.2307/256404

Panaccio, A., Vandenberghe, C., \& Ben Ayed, A.K. (2014). The role of negative affectivity in the relationships between pay satisfaction, affective and continuance commitment and voluntary turnover: A moderated mediation model. Human Relations, 67(7), 821-848. https://doi.org/10.1177/0018726713516377

Park, Y., Song, J.H., \& Lim, D.H. (2016). Organizational justice and work engagement: the mediating effect of self-leadership. Leadership \& Organization Development Journal, 37(6), 711-729.

Podsakoff, P.M., MacKenzie, S.B., Lee, J., \& Podsakoff, N.P. (2003). Common method biases in behavioral research: A critical review of the literature and recommended remedies. Journal of Applied Psychology, 88(5), 879-903.

Pretorius, L. (2018). Are $60 \%$ of TVET colleges a failure? City Press. Retreived from https://www.news24.com/citypress/news/are-60-of-tvet-colleges-a-failure-20181217

Pritchard, R.D. (1969). Equity theory: A review and critique. Organizational Behavior and Human Performance, 4(2), 176-211. https://doi.org/10.1016/0030-5073(69) 90005-1

Putri, W.H., \& Setianan, A.R. (2019). Job enrichment, organizational commitment, and intention to quit: The mediating role of employee engagement. Problems and Perspectives in Management, 17(2), 518-526. https://doi.org/10.21511/ and Perspectives in

Reddy, V., Rogan, M., Mncwango, B., \& Chabana, S. (2017). Occupations in high demand in South Africa: A technical report. Pretoria: Labour Market Intelligence Partnership.

Rhoades, L., Eisenberger, R., \& Armeli, S. (2001). Affective commitment to the organization: The contribution of perceived organizational support. Journal of Applied Psychology, 86(5), 825. https://doi.org/10.1037/0021-9010.86.5.825

Robbins, S. (1993). Organisational behaviour: Concepts, controversies, and applications (6th edn.). Englewood Cliffs, NJ: Prentice Hall.

Roodt, G. (2004). Turnover intentions. Unpublished document, University of Johannesburg.

Sachau, D.A. (2007). Resurrecting the motivation-hygiene theory: Herzberg and the positive psychology movement. Human Resource Development Review, 6(4), 377-393. https://doi.org/10.1177/1534484307307546

SA Commercial Prop News. (2013). SA running short of Artisan skills. Retreieved from http://www.sacommercialpropnews.co.za/construction-industry/5944-sa-runningshort-of-artisan-skills.html

Saks, A.M. (2006). Antecedents and consequences of employee engagement. Journal of Managerial Psychology, 21(7), 600-619. https://doi.org/10.1108/ 02683940610690169

Saleem, S., \& Qamar, B. (2017). An investigation of the antecedents of turnover intentions and job hopping behavior: An empirical study of universities in Pakistan. South Asian Journal of Business Studies, 6(2), 161-176. https://doi. org/10.1108/SAJBS-05-2016-0046

Schlechter, A., Faught, C., \& Bussin, M. (2014). Total rewards: A study of artisan attraction and retention within a South African context. South African Journal of Human Resource Management, 12(1), 1-15. https://doi.org/10.4102/sajhrm.v12i1.648

Shapiro, H.J., \& Wahba, M.A. (1978). Pay satisfaction: An empirical test of a discrepancy model. Management Science, 24(6), 612-622. https://doi.org/10.1287/mnsc. 24.6.612

Siemsen, E., Roth, A., \& Oliveira, P. (2010). Common method bias in regression models with linear, quadratic, and interaction effects. Organizational Research Methods, 13(3), 456-476. https://doi.org/10.1177/1094428109351241

Siers, B. (2007). Relationships among organisational justice perceptions, adjustment, and turnover of United States-based expatriates. Applied Psychology, 56(3), 437-459. https://doi.org/10.1111/j.1464-0597.2007.00269.x 
SimanTov-Nachlieli, I., \& Bamberger, P. (2020). Pay communication, justice, and affect: The asymmetric effects of process and outcome pay transparency on counterproductive workplace behavior. Journal of Applied Psychology, 106(2) 230-249. https://doi.org/10.1037/apl0000502

Song, W., Yu, H., Zhang, Y., \& Jiang, W. (2015). Goal orientation and employee creativity: The mediating role of creative role identity. Journal of Management and Organization, 21(1), 82-97. https://doi.org/10.1017/jmo.2014.64

Spector, P.E. (2019). Do not cross me: Optimizing the use of cross-sectional designs. Journal of Business and Psychology, 34(2), 125-137. https://doi.org/10.1007/ s10869-018-09613-8

Sturges, J., Conway, N., Guest, D., \& Liefooghe, A. (2005). Managing the career deal The psychological contract as a framework for understanding career management, organizational commitment and work behavior. Journal of Organizational Behavior, 26(7), 821-838. https://doi.org/10.1002/job.341

Suifan, T.S., Diab, H., \& Abdallah, A.B. (2017). Does organizational justice affect turnover-intention in a developing country? The mediating role of job satisfaction and organizational commitment. Journal of Management Development.

Sun, K.-S. (2011). The turnover intentions for construction engineers. Journal of Marine Science and Technology, 19(5), 550-556.

Sutherland, M., \& Jordaan, W. (2004). Factors affecting the retention of knowledge workers. SA Journal of Human Resource Management, 2(2), 55-64. https://doi. org/10.4102/sajhrm.v2i2.39

Takawira, N., Coetzee, M., \& Schreuder, D. (2014). Job embeddedness, work engagement and turnover intention of staff in a higher education institution: An exploratory study. SA Journal of Human Resource Management, 12(1), 1-10. https://doi.org/10.4102/sajhrm.v12i1.524

Taris, T.W., Horn, J.E. Van Schaufeli, W.B., \& Schreurs, P.J.G. (2004). Inequity, burnout and psychological withdrawal among teachers: A dynamic exchange model. Anxiety, Stress \& Coping, 17(1), 103-122. https://doi.org/10.1080/10615 80031000151620

Tebele, C., Van Dyk, J., \& Coetzee, M. (2013). Organisational commitment and job embeddedness of service staff with critical and scarce skills. South African Journal of Labour Relations, 37(1), 61-78.

The Department of Trade and Industry. (2015). Facts and figures on skills in manufacturing. Retrieved from www.thedti.gov.za
Till, R.E., \& Karren, R. (2011). Organizational justice perceptions and pay level satisfaction. Journal of Managerial Psychology, 26(1), 42-57. https://doi.org/ 10.1108/02683941111099619

Tshele, L., \& Agumba, J.N. (2014). Investigating the causes of skills shortages in South African construction industry: The case of artisans. In TG59 'People in Construction' Conference (pp. 101-110). Port Elizabeth.

Van Rooyen, L., Du Toit, D.H., Botha, E., \& Rothmann, S. (2010). Artisan retention in an organisation in South Africa. South African Journal of Human Resource Management, 8(1), 1-8. https://doi.org/10.4102/sajhrm.v8i1.300

Wang, H., Ma, B., Liu, X., \& Liu, S. (2014). Job security and work outcomes in China: Perceived organizational support as mediator. Social Behavior and Personality: An International Journal, 42(7), 1069-1076. https://doi.org/10.2224/sbp.2014. 42.7.1069

Weng, Q., \& Hu, B. (2009). The structure of career growth and its impact on employees' turnover intention. Industrial Engineering and Management, 14(1), 14-21.

Weng, Q., McElroy, J.C., Morrow, P.C., \& Liu, R. (2010). The relationship between career growth and organizational commitment. Journal of Vocational Behavior 77(3), 391-400. https://doi.org/10.1016/j.jvb.2010.05.003

Weston, R., \& Gore, Jr. P.A. (2006). A brief guide to structural equation modeling. The Counseling Psychologist, 34(5), 719-751. https://doi.org/10.1177/0011 000006286345

Willemse, M., \& Deacon, E. (2015). Experiencing a sense of calling: The influence of meaningful work on teachers' work attitudes. SA Journal of Industrial Psychology, 41(1), 1-9. https://doi.org/10.4102/sajip.v41i1.1274

Williams, M.L., McDaniel, M.A., \& Nguyen, N.T. (2006). A meta-analysis of the antecedents and consequences of pay level satisfaction. Journal of Applied Psychology, 91(2), 392. https://doi.org/10.1037/0021-9010.91.2.392

Wong, Y.-W., \& Wong, Y. (2017). The effects of perceived organisational support and affective commitment on turnover intention: A test of two competing models. Journal of Chinese Human Resource Management, 8(1), 2-21. https://doi. org/10.1108/JCHRM-01-2017-0001

Woods, S.A., \& West, M.A. (2014). The psychology of work and organizations. In The psychology of work and organisations (2nd edn.). Cengage Learning. Retreived psychology of work and organisations $(2$ nd
from https://doi.org/10.1037/13167-012

Xpatweb. (2020). New critical skills survey: The most in-demand skills per DHET draft list and skilled saffers leaving the country fuels the skills gap. Retrieved from https://www.xpatweb.com/news/news-new-critical-skills-survey-the-most-indemand-skills/ 